Western University

Scholarship@Western

Law Publications

Law School

2014

\title{
A Hague Convention on Contract Pregnancy (or 'Surrogacy'): Avoiding Ethical Inconsistencies with the Convention on Adoption
}

Andrew Botterell

Western University, abottere@uwo.ca

Carolyn McLeod

Western University, cmcleod2@uwo.ca

Follow this and additional works at: https://ir.lib.uwo.ca/lawpub

Part of the Family Law Commons, and the International Law Commons

Citation of this paper:

Botterell, A. and C. McLeod, "A Hague Convention on Contract Pregnancy (or 'Surrogacy'): Avoiding Ethical Inconsistencies with the Convention on Adoption," International Journal of Feminist Approaches to Bioethics 7:2 (2014): 219-235. 


\title{
A HAGUE CONVENTION ON CONTRACT PREGNANCY (OR 'SURROGACY'): AVOIDING ETHICAL INCONSISTENCIES WITH THE CONVENTION ON ADOPTION
}

By Carolyn McLeod and Andrew Botterell, forthcoming in IJFAB 7(2), 2014

\begin{abstract}
In the past, the Hague Conference on Private International Law has shaped how people can become the legal parents of children born in countries other than their own. It did so by creating the 1993 Hague Convention on Intercountry Adoption. It is now interested in developing a convention on international contract pregnancy (or what many call surrogacy). We discuss in this commentary what such a convention would have to include for it to be ethically consistent with the Convention on Adoption.
\end{abstract}

\section{Introduction}

The Hague Conference on Private International Law is currently considering the development of a Hague Convention on international contract pregnancy. Recently, the Permanent Bureau of the Conference published "A Preliminary Report on the Issues Arising from International Surrogacy Arrangements" (2012). There it acknowledges that overlap may exist in the proper regulation of international adoption and international contract pregnancy (contract pregnancy being a more neutral term, morally speaking, than surrogacy). The report states that "some of the techniques employed by the 1993 Convention [on Protection of Children and Co-operation in Respect of Intercountry Adoption] may be of relevance to international surrogacy" (29). Our topic concerns what these "techniques" might be, or, more generally, the extent to which conventions on these two practices should resemble one another. We are especially interested in what a Hague Convention on contract pregnancy would have to be like in order for it to be ethically consistent 
with the Hague Convention on Adoption, given similarities and differences between contract pregnancy and adoption.

Here, we identify issues that are relevant to making the one convention (on contract pregnancy) ethically consistent with the other (on adoption). At a minimum, the following four issues are relevant in our opinion: support for the practice - whether or to what extent a convention on contract pregnancy should support or promote contract pregnancy ${ }^{1}$; consentwhat such a convention should require in terms of consent from contract pregnant women; sale of children - whether or, more importantly, how it should prohibit their sale; and parental vetting — whether it should demand that individuals be prevented from pursuing contract pregnancy unless the state in which they live has determined that they would be good or good enough parents. These issues are not necessarily exhaustive; there may be others that bear on whether a convention on contract pregnancy is ethically consistent with the Convention on Adoption. Nonetheless, these four issues are of central importance. Moreover, in our view they ought to be treated in a convention on contract pregnancy similarly to how they are treated in the Convention on Adoption. ${ }^{2}$ Thus, the former convention ought to have similar requirements as the latter with respect to consent or parental vetting, for example. The reasons for such similarity include fairness along with other ethical demands, such as respect for persons.

\section{Support for the Practice}

A Hague Convention on contract pregnancy would serve to regulate, at an international level, the burgeoning global market in contract pregnancies. ${ }^{3}$ The report of the Permanent Bureau calls for such regulation, particularly for the sake of children born through contract pregnancy, some of whom have been left "marooned, stateless and parentless" because of conflicting legal 
approaches to contract pregnancy in different countries (Permanent Bureau 2012, 4; citing $\operatorname{Re} X$ $\& Y$ ). The main purpose of the convention, according to the report, would be to prevent such cases from occurring. ${ }^{4}$ We agree with this aim, and also note that a similar aim existed in creating the Convention on Adoption: that is, to ensure that an adoption recognized in the "State of origin" (i.e., the state in which the child was born) would also be recognized in "the receiving State." ${ }^{5}$ The Convention on Adoption satisfies this objective while at the same time remaining neutral about the practice of intercountry adoption: it does not promote this practice - that is, encourage any State to accept it. We believe that a convention on contract pregnancy should similarly be neutral with respect to contract pregnancy.

The Convention on Adoption prevents adoptions from going forward that might "maroon" children by requiring that the proposed State of origin and the receiving State agree "that the adoption may proceed" before it does so (Article 17, sub-paragraph c). The Convention does not require of all States that are signatories to it ("Contracting States") that they support adoption; a Contracting State might never allow an adoption to proceed. Consequently, the Convention itself does not promote this practice. ${ }^{6}$ Granted, it outlines circumstances in which an adoption is permissible; however, the Convention is consistent with there being no permissible adoptions because no Contracting State ever agrees with an adoption.

A convention on contract pregnancy could similarly prevent the marooning of children who are born through contract pregnancy without actively promoting these arrangements (Trimmings and Beaumont 2011). For the Convention needn't require of Contracting States that they recognize all or any pregnancy contracts. Instead, like the Convention on Adoption, it could demand that before a contract pregnancy arrangement occurs, the two states involved in the arrangement agree to it and the receiving State consents to allow any resulting child to cross its 
borders and be or become the legal child of the commissioning couple (Permanent Bureau 2012, 30; Trimmings and Beaumont 2011). ${ }^{7}$ A convention that employed this technique would not support contract pregnancy.

To be sure, having a convention on contract pregnancy that did support contract pregnancy would not be feasible. To expect that member States would all accept international contract pregnancy, which tends to be commercial rather than altruistic, is unrealistic. There is simply too much global opposition to this practice (Permanent Bureau 2012, 7). Thus, considerations having to do with feasibility suggest that the convention must be neutral about whether contract pregnancy should be permitted.

However, considerations of fairness may also require that this convention be neutral given that the Convention on Adoption is similarly neutral. In other words, it would be unfair for the Hague Conference to promote contract pregnancy but not adoption - that is, to favour the one way of forming a family with children over the other-unless it could be shown that contract pregnancy was ethically superior to adoption. Attempts to prove such a claim of superiority are, however, a lost cause in our opinion.

For example, some will insist that contract pregnancy is ethically superior on the grounds that people have a right to pursue it - that is, they have a right to reproduce — whereas people do not have a right to adopt children. On this view, contract pregnancy should be permittedContracting States should not be able to block these arrangements-because they allow people to reproduce and people have a right to do so (see, e.g., Gamble 2012). But the same is not true of adoption: people who become parents through adoption do not exercise a right to reproduce or any similar right. Thus, according to this argument, Contracting States are ethically entitled to stand in the way of adoption but not of contract pregnancy, and a convention on contract 
pregnancy that prohibited such interference would not be ethically inconsistent with the Convention on Adoption, which offers no similar support for adoption.

Elsewhere, we question how relevant the right to reproduce is to contract pregnancy (McLeod \& Botterell, unpublished manuscript) and even whether people have such a right as opposed to merely a right to become a parent (Botterell \& McLeod, forthcoming). We summarize these positions below. For the moment, however, let us suppose that the right to reproduce $i s$ genuine and that people who engage in contract pregnancy exercise this right. Even so, it is still not obvious to us that the Hague Conference should support contract pregnancy-in particular by requiring that Contracting States accept it—while refusing to support adoption in the same way.

For while prospective adoptive parents may not have a right to adopt children, children who are in need of parents have a right to have parents (good or good enough parents). Indeed, their welfare often depends on it. ${ }^{8}$ Worldwide, there are an estimated 8-12 million children who live in institutions (Bartholet forthcoming, citing Save the Children 2009; see also Rulli 2014, citing Secretary-General 2006), and roughly 18 million children orphaned through the death of both biological parents (Bartholet forthcoming). In general, these children need parents but are not all likely to get them through intracountry (relative or non-relative) adoption, nor through foster care. So long as that is the case, moreover, there will be a need for intercountry adoption. The international community therefore has a powerful child-centered reason to support this practice, ${ }^{9}$ a reason that is surely as strong as any reason it has to promote contract pregnancy. Consequently, the Hague Conference, and the international community more generally, should not support contract pregnancy while remaining neutral about adoption. 
In short, so long as the Hague Conference is neutral with respect to whether states should permit adoption, it should be neutral with respect to whether they should permit contract pregnancy. To embrace a more supportive stance toward contract pregnancy would be unfair to children who need parents and have a right to have them. For what it's worth, we object to the neutrality of the international community with respect to the need that millions of children worldwide have for parents. At the same time, we think that a neutral stance is appropriate-if perhaps too permissive - with respect to contract pregnancy. We see, in other words, an important asymmetry between intercountry adoptions and international contract pregnancy, the latter being normatively more suspect than the former. Governments and international bodies should work to improve systems of adoption, both domestic and international, for the sake of children who need families. But there is no moral imperative for them to work simultaneously to enhance opportunities people have for engaging in contract pregnancy. Our reasons in favour of this position include, but are not limited to, our skepticism toward the idea that people have a right to reproduce (see below).

From our point of view then, on the issue of support for the practice, the Hague Convention should make its convention on contract pregnancy similar to the existing Convention on Adoption, but should revise the latter to make it more supportive of adoption. That said, our purpose in this section was not to defend this position but simply to show what the Hague Conference is committed to in terms of promoting contract pregnancy, given the level of support it currently gives to adoption.

Before moving on from support for the practice to the issue of consent, we want to make one point about language. If a convention on contract pregnancy is to be neutral or unbiased with respect to what many call surrogacy, then it should adopt the term contract pregnancy instead. 
The latter is more neutral because it does not suggest that the woman who carries the child is merely a substitute for the real mother or real caregiver of the child (Satz 1992, 107, note 2). ${ }^{10}$ It is an open question, both legally in some jurisdictions and morally, whether a child that a woman agrees to gestate for someone else - a child who may or may not be genetically related to hershould be recognized as her child. Since we strive to be open in this regard, we refer to contract pregnancy not surrogacy, and believe that any Hague Convention should do the same.

\section{Consent}

According to Article 4 sub-paragraph c) of the Convention on Adoption,

[a]n adoption within the scope of the Convention shall take place only if the competent authorities of the State of origin ... have ensured that,

(1) the persons, institutions and authorities whose consent is necessary for adoption, have been counseled as may be necessary and duly informed of the effects of their consent, in particular whether or not an adoption will result in the termination of the legal relationship between the child and his or her family of origin,

(2) such persons, institutions and authorities have given their consent freely, in the required legal form, and expressed or evidenced in writing,

(3) the consents have not been induced by payment or compensation of any kind and have not been withdrawn, and

(4) the consent of the mother, where required, has been given only after the birth of the child.

Let us discuss (1) to (4) with an eye toward assessing whether similar statements should appear in any convention on contract pregnancy.

We assume it is uncontroversial that a Convention on Contract Pregnancy must include statements similar to (1) and (2) above. Moreover, among the parties "whose consent is necessary for" contract pregnancy is, of course, the contract pregnant woman herself. She should 
be protected from coercion and accorded respect for her autonomy for the very same reasons that the biological family or guardians of a child in an adoption are required to give their full and informed consent to the adoption.

We take it that the first part of statement (3) above - that the consents not be induced by payment or compensation of any kind — concerns the sale of children. Here and elsewhere, the Convention on Adoption prohibits such sales. We discuss this issue in the next section. For present purposes, however, it suffices to note that if providing some compensation to a contract pregnant woman is possible without engaging in "baby selling" (and we think it is), then a convention on contract pregnancy need not prohibit all "consents" that are induced by payment. Nonetheless, in its section on consent it should, for the sake of the autonomy of contract pregnant women, object to any so-called "consent" that is unduly induced by payment (i.e., where the offer of payment was coercive). ${ }^{11}$

Statement (4) above, and that part of statement (3) that concerns the withdrawal of consent, are controversial when applied to contract pregnancy. Among the questions they raise for this practice, the most difficult is whether contract pregnant women should be able to change their minds about continuing with a contract pregnancy or about relinquishing the child they gestate. (There is also the question of whether commissioning couples should be able to change their minds about raising the child, but we will leave this issue aside in the interests of space and because we believe it to be significantly less difficult.) Some would claim contract pregnant women should not be able to revoke their consent at any stage, because the child they gestate is not their child. But such a restriction arguably fails to respect women's bodily autonomy in pregnancy. ${ }^{12}$ It also signals a lack of openness about whether a contract pregnant woman is a mother to the child she gestates. If she is a mother and mothers are able to change their minds 
about transferring responsibility for their children to others (as in an adoption), then the contract pregnant woman should not be prevented from doing so.

The situation is arguably more complicated, however, with contract pregnancy than with adoption, because at least one member of the commissioning couple in a contract pregnancy can typically claim to be a parent (a genetic parent) to the child before the transfer of responsibility for that child occurs, which is not the case for prospective adoptive parents. Thus, the risk in allowing contract pregnant women to revoke their consent is that some people are prevented from parenting their children, assuming that genetics (or perhaps intention) can ground parenthood (see Bayne and Kolers 2003). But notice that the risk is identical in not allowing these women to revoke their consent: some people (i.e., the contract pregnant women) are prevented from parenting their children, assuming here that gestation can ground parenthood (see, again, Bayne and Kolers 2003). Hence, it would be problematic if a convention on contract pregnancy did the opposite to the Convention on Adoption and made all consents irrevocable, thereby privileging the interests of commissioning "parents." At the very least, ${ }^{13}$ a convention on contract pregnancy should remain non-committal about whether a withdrawal of consent by the contract pregnant woman is possible.

Withdrawal of consent for a contract pregnancy may be a complicated matter; but consent to such a pregnancy is just as important as consent to an adoption. ${ }^{14}$ The children who would be protected by a convention on contract pregnancy should not have even come into being unless the woman who bore them freely agreed to do so. Similarly, children who are protected by the Convention on Adoption should not be available for adoption unless their birth parents or legal guardians relinquished them freely. 


\section{Sale of Children}

The Convention on Adoption explicitly forbids "the sale of, or traffic in children" (Preamble, Article 1 sub-paragraph b). And any convention on contract pregnancy should do the same. But what does it mean to prohibit "baby selling" in the context of contract pregnancy?

In our view, in order to prevent the sale of children, a convention on contract pregnancy should, at a minimum, require that where the contract pregnancy is commercial, the contract pregnant woman be paid regardless of whether she gestates a live child. ${ }^{15}$ In other words, she must receive some remuneration even if she has a miscarriage or a stillbirth. To be sure, she could be paid beyond reasonable expenses and not be selling a child, for the payment could be

for her labor rather than for the child. ${ }^{16}$ Commercial contract pregnancy amounts to baby selling not necessarily when the woman is paid, but when she is paid only if there is a live child in the end. Some international contract pregnancy is of the latter sort (Busby and Vun 2010, Pande 2010; cited in Panitch 2013, 332), and a convention on contract pregnancy should prohibit it.

Katarina Trimmings and Paul Beaumont insist instead that to prevent the sale of children, the convention should specify a "remuneration maximum" $(2011,644)$. No commercial contract pregnancy arrangements should exceed this maximum, in their view. However, such a measure would not eliminate the sale of children. For commercial arrangements that set payment below the maximum would still involve such sales if the payment was conditional on the pregnancy producing a live (and perhaps healthy) baby. Whenever payment is conditional on producing a certain "good" (e.g., a house), the payment is, at least in part, for that good (the house).

One might think that the convention should impose a remuneration maximum in addition to requiring that women be paid in commercial arrangements regardless of the outcome of their pregnancy. Such a combination would guard against cases where the commissioning couple is 
willing to pay a premium to get a "designer baby" - that is, a child with characteristics that they covet — and is willing to risk there being no live baby in the end. Arguably, here what the couple pays for is not simply the pregnant woman's labor, but a baby—one of a certain kind. In response to this objection, it should be pointed out that the individual the commissioning couple would pay to get their designer child is not the contract pregnant woman, but an egg donor. For various reasons, most contract pregnancy is gestational, which means that the contract pregnant woman is not genetically related to the future child she gestates. She would not be paid exorbitant amounts so that the commissioning couple could have a certain sort of baby; an egg donor would. Thus, although there should probably be a remuneration maximum for the global egg trade, it is not obvious that there needs to be such a maximum for the global trade in women's gestational labor.

A more pressing question is whether there should be a remuneration minimum for the labor involved in conceiving and gestating a child for others. The aim in imposing a minimum would be to prevent the exploitation of poor or disenfranchised women. We favour such a measure, but recognize the difficulty in coming up with an amount that would not unduly induce some women to engage in contract pregnancy. ${ }^{17}$

To return to the matter at hand, given that the sale of children is forbidden in the context of adoption (and rightly so), it should likewise be forbidden in the context of contract pregnancy. What this means for commercial contract pregnancy is that women who sell their gestational labor should get paid even if the future child dies during the pregnancy or birth. There should be an Article in a convention on contract pregnancy that makes payment in these circumstances obligatory. 


\section{Parental Vetting}

One final issue we would like to discuss concerns parental vetting or licensing. ${ }^{18}$ Does ethical consistency with the Convention on Adoption demand that any convention on contract pregnancy include a requirement of parental vetting? The Convention on Adoption has such a requirement: Article 5, sub-paragraph a) states that "[a]n adoption within the scope of the Convention shall take place only if the competent authorities of the receiving State have determined that the prospective adoptive parents are eligible and suited to adopt." We believe that a similar article should appear in any convention on contract pregnancy.

Let us first say that we are not alone in our opinion about parental vetting. Katarina Trimmings and Paul Beaumont, ${ }^{19}$ who are cooperating with the Permanent Bureau in its efforts to develop a convention on contract pregnancy (Permanent Bureau 2012, 6), are in favour of a parental licensing requirement $(2011,642)$. However, they give no explanation for why this convention should mimic the Convention on Adoption in this regard, and one might question whether such a technique for protecting children is appropriate for contract pregnancy. One might think that, after all, contract pregnancy is a form of reproduction - it "belongs to the world of reproduction rather than adoption" (Gamble 2012, 311) —and people who reproduce are generally not subject to parental licensing. Furthermore, most jurisdictions do not require any such licensing for people who commission pregnancies (although some jurisdictions will not legally recognize a pregnancy contract unless the commissioning couple is suitable to parent any resulting child or children ${ }^{20}$ ).

Elsewhere, we argue that there are no good moral reasons for what we call the "status quo" on parental licensing, according to which there should be licensing with adoption but not with assisted or unassisted reproduction (McLeod \& Botterell 2014; Botterell \& McLeod, 
forthcoming) ${ }^{21}$ We also think the reasons typically given for insisting that there be licensing for adoption, but not for contract pregnancy, are particularly bad. Since we cannot discuss all of these reasons here, ${ }^{22}$ let us simply focus on one of them—one that concerns a right to reproduce — and summarize why we believe it is weak.

The target reasoning or argument is this: while parental licensing would violate the right to reproduce of people who want to become parents via contract pregnancy, it violates no such right for people who want to adopt a child. Hence, licensing is unjustified in the context of contract pregnancy, but justified in the context of adoption.

Our response to this argument is twofold. First, some people who seek to become parents through contract pregnancy will not reproduce through this practice. We have in mind members of commissioning couples whose gametes are not used in the process of conception. These people will have neither a genetic nor a gestational connection to any resulting children. Hence, they cannot possibly be said to be reproducing or to be exercising a right to reproduce. This right, therefore, could not protect them against interference in the form of state-imposed licensing.

Second, even when people do reproduce through contract pregnancy, it is not obvious to us that they have or are exercising a right to do so (which is not to say, of course, that such action is morally impermissible). In our previous work, we distinguish between a right to reproduce and a right to become a parent. ${ }^{23} \mathrm{We}$ think that the reasons people can have for wanting to become a parent, of any kind, can be very good (see also Brighouse and Swift 2006); but the same is not true of reasons for wanting to become a genetic parent. Various philosophers have critiqued the desire that many people have to be genetically related to their children (see Levy \& Lotz 2005, Friedrich 2013, Overall 2014, Rulli unpublished manuscript). They argue 
that often this desire is based on a naïve view of genetics (e.g., that family resemblances are mainly genetic), on a problematic conception of the parent-child relationship (i.e., that a child is not truly one's own unless one is genetically related to him or her), or on false beliefs about adoption (e.g., that people tend not to love adopted children as much as they do their "own" children). In other words, underlying the preference to be a genetic parent are beliefs or opinions that find no support within the science of genetics, moral analyses of the parent-child relationship, or empirical evidence about adoption and adopted children. Hence, they should be rejected. However, without them, a right to reproduce genetically has no basis. We are therefore skeptical of this right and resist the idea that because of it, there should be unfettered access to contract pregnancy for people who seek to become genetic parents through this practice.

Thus, based on others' critiques of a preference for genetically related children as well as our previous work on parental vetting, we conclude that a right to reproduce cannot protect prospective parents of children born contract pregnancy from being vetted as parents. Some of the people who choose this route to parenting do not even reproduce. The fact that others do reproduce, however, is not in our opinion morally relevant to whether they should be subject to parental licensing. In short, if prospective adoptive parents have to undergo such scrutiny, then prospective parents of children born through contract pregnancy should have to as well.

\section{Conclusion}

Our aim in this commentary has been to explain how, in certain respects, a convention on contract pregnancy could be ethically consistent with the Convention on Adoption. We have claimed, in brief, that a convention on contract pregnancy should do the following: not support this practice and therefore not insist that Contracting States accept it; require full and informed 
consent from contract pregnant women and, at a minimum, remain non-committal about whether a withdrawal of consent from these women is possible; demand that contract pregnant women be paid regardless of whether they deliver a live child; and require that the commissioning couple be vetted, just as prospective adoptive parents are vetted. Incorporating these requirements into a convention on contract pregnancy would go some distance towards rendering it ethical. They are important for the sake of ethical consistency between the two conventions and also to ensure the ethical soundness of a convention on contract pregnancy considered on its own.

Ethical consistency has been our main focus for two reasons. First, we wanted to highlight what we believe the Hague Conference is committed to with respect to contract pregnancy, given what it has committed itself to with respect to adoption. As indicated above, we do not think that the Hague Conference can justify treating the two practices differently simply because the one (contract pregnancy) involves reproduction, while the other (adoption) does not. The report of the Permanent Bureau states that "surrogacy is a form of procreation" and this feature makes it importantly different from adoption (29, ftn 171). However, the moral significance of this difference is questionable. Although in some respects it may be morally significant that contract pregnancy involves procreation (or can do so for certain parties), in other respects—-for example, whether there should be parental vetting — it is not significant, in our opinion.

Second, like others (e.g., Bartholet forthcoming), we are concerned that the rights and prospects of children worldwide who are currently without parents are being detrimentally affected by the phenomenon of international contract pregnancy (and by other forms of assisted reproduction). By focusing on ethical consistency and ethical similarities between these practices, we have gone some way toward resisting this tendency. In light of the rapid growth of 
international markets in contract pregnancy, it is vital in our opinion that the international community recognize the value of adoption (see Rulli 2014) and view adoption as morally equivalent at least, if not morally superior, to contract pregnancy.

\section{Notes}

${ }^{1}$ For ease of exposition, we refer simply to contract pregnancy rather than international contract pregnancy, unless we need to emphasize the international dimension of this practice. We do the same with adoption, as opposed to intercountry adoption.

${ }^{2}$ This is not to say that the Convention on Adoption is perfect (for criticism, see Bartholet unpublished manuscript), although we do think that this Convention deals with most of the above matters appropriately. The exception is support for the practice, as discussed below.

${ }^{3}$ States that ratify the convention would thereby have the legal obligations set out within it (Valerie Oosterveld, personal communication).

${ }^{4}$ The report also mentions the need to protect vulnerable "surrogate mothers," but does not focus on this problem $(2012,26)$.

${ }^{5}$ See Baker $(2013,416-17)$. However, according to her, the main impetus behind the Convention on Adoption was to prevent the sale and trafficking of children.

${ }^{6}$ The most that the Convention says in support of this practice is that "intercountry adoption may offer the advantage of a permanent family to a child for whom a suitable family cannot be found in his or her State of origin" (Preamble; our emphasis). 
${ }^{7}$ For ease of exposition, we refer to a commissioning couple, rather than a commissioning individual, even though in some cases there is only an individual (i.e., only one prospective parent).

${ }^{8}$ See, e.g., Friedrich $(2013,25)$ and Rulli (2014). As Rulli notes, “[a]bsent a stable family and the benefits of constant care and attention, children are at risk of severe physical, cognitive, and emotional deficits. Adoption can not only prevent these deficits of institutional care, but for those children who experience neglect and abuse prior to adoption, it is the best cure" (109). Support for this last point comes from a recent review of studies indicating that many children make a "remarkable recovery" from early adversity when they are adopted (Blake et al 2014, 76; citing Palacios and Brodzinsky 2010). See also Van Ijzendoorn and Juffer 2006 (cited in Rulli 2014).

${ }^{9}$ That is, support it so long as it is done ethically and the biological parents are not coerced to give up their children (see the next section on consent).

${ }^{10}$ See also Okin (1990), cited in Baylis (2014). The term contract pregnancy is also appropriate given that the international market for women's reproductive labor usually requires that buyers sign agreements or contracts. This is true, for example, in India (see Baylis, 265 note 1).

${ }^{11}$ On coercive offers, see Harry Frankfurt, who writes that an offer is coercive when the recipient is "moved into compliance by a desire which is not only irresistible, but which he would overcome if he could" $(1988,42)$.

${ }^{12}$ For opposing views, see Shalev 1989 and Shultz 1990.

${ }^{13}$ At the most - and more controversially_it could insist that pregnancy contracts include pre-birth and post-birth opt-out clauses for contract pregnant women. Notice that by 
insisting on post-birth opt-out clauses, the Convention would be prohibiting "pre-birth orders," which make the child "automatically the legal child of the intending parents at birth" (Permanent Bureau 2012, 17). Some States allow pre-birth orders for contract pregnancy.

${ }^{14}$ As Vida Panitch suggests, however, justice (of the distributive kind) is also an important consideration. The "distribution of benefits and harms" between the contract pregnant woman and the commissioning couple should not be unfair to the former, as it often is (Panitch 2013, 331). If it is unfair, then the contract pregnancy is wrongfully exploitative, that is, regardless of whether it is consensual.

${ }^{15}$ Other requirements may be necessary. For example, we are open to a suggestion made by one of the reviewers for this paper that baby selling occurs when contract pregnancies are arranged by brokers who make inordinate amounts of money.

${ }^{16}$ On the labor involved in domestic contract pregnancy, see McLeod (2007, 263-64). Much of what is said here applies equally well to international contract pregnancy.

${ }^{17}$ For a discussion of how the same issue — that of undue inducement —arises in the global trade in human eggs for research, see Baylis and McLeod (2007).

${ }^{18}$ We use the term licensing in our previous work and use it here interchangeably with vetting. Both terms refer to restrictions on people's freedom to parent a child that the state imposes on them even though they may have never mistreated children. A state that vets or licenses parents requires that individuals show some competency in being a parent before they become one in a social sense (Botterell and McLeod forthcoming; McLeod and Botterell 2014). Current licensing for adoptive parents involves a home study and sometimes, mandatory parenting classes as well. 
${ }^{19}$ They have a Nuffield Foundation grant to work on international contract pregnancy. See http://www.abdn.ac.uk/law/research/international-surrogacy-arrangements-151.php.

${ }^{20}$ South Africa is an example. According to its Children's Act 2005, "a court may not confirm a surrogate motherhood arrangement unless the commissioning parent or parents are in all respects suitable persons to accept the parenthood of the child that is to be conceived" (295 (b)(ii)). See http://www.info.gov.za/view/DownloadFileAction?id=67892.

${ }^{21}$ This description simplifies the status quo. For the complexities of it, see McLeod and Botterell (2014).

${ }^{22}$ We discuss them in McLeod and Botterell, unpublished manuscript.

${ }^{23}$ We also distinguish these rights from a right to parent one's biological baby. See Gheaus (2012).

\section{References}

Baker, Hannah. 2013. "A Possible Future Instrument on International Surrogacy Arrangements: Are There 'Lessons' to be Learnt from the 1993 Hague Intercountry Adoption Convention?" In International Surrogacy Arrangements: Legal Regulation at the International Level, ed. Katarina Trimmings and Paul Beaumont, 411-26. Oxford: Hart Publishing.

Bartholet, Elizabeth. Forthcoming. "Intergenerational Justice for Children: Restructuring Adoption, Reproduction, and Child Welfare Policy," Journal of Law \& Ethics of Human Rights, accessed April 23, 2014, http://papers.ssrn.com/sol3/papers.cfm?abstract_id=2282012. 
---. Unpublished manuscript. "The Hague Convention: Pros, Cons and Potential,” accessed April 23, 2014, http://papers.ssrn.com/sol3/papers.cfm?abstract_id=2279583.

Baylis, Françoise. 2014. “Transnational Commercial Contract Pregnancy in India.” In Baylis and McLeod, Family-Making: 265-86.

Baylis, Françoise, and Carolyn McLeod, eds. 2014. Family-Making: Contemporary Ethical Challenges. Oxford UK: Oxford University Press.

---. 2007. "The Stem Cell Debate Continues: The Buying and Selling of Eggs for Research," Journal of Medical Ethics 33 (12): 726-31.

Bayne, Tim, and Avery Kolers. 2003. "Parenthood and Procreation.” In the Stanford Encyclopedia of Philosophy, accessed April 22, 2014, http://plato.stanford.edu/archives/spr2003/entries/parenthood/

Blake, Lucy, Martin Richards, and Susan Golombok. 2014. "The Families of Assisted Reproduction and Adoption.” In Baylis and McLeod, Family-Making: 64-85.

Botterell, Andrew and Carolyn McLeod. Forthcoming. "Can a Right to Reproduce Justify the Status Quo on Parental Licensing?” In Permissible Progeny, ed. Richard Vernon, Sarah Hannan, and Samantha Brennan. New York: Oxford University Press.

Brighouse, Harry and Adam Swift. 2006. "Parents' Rights and the Value of the Family," Ethics, 117 (1): 80-108.

Busby, Karen and Delaney Vun. 2010. "Revisiting the Handmaid's Tale: Feminist Theory Meets Empirical Research on Surrogate Mothers," Canadian Journal of Family Law 26 (1): 1393.

Frankfurt, Harry. 1988. The Importance of What We Care About: Philosophical Essays. Cambridge, UK: Cambridge University Press. 
Friedrich, Daniel. 2013. “A Duty to Adopt?” Journal of Applied Philosophy 30 (1): 25-39.

Gamble, Natalie. 2012. "Surrogacy: Creating a sensible national and international legal framework," International Family Law, September: 308-11.

Gheaus, Anca. 2012. “The Right to Parent One’s Biological Baby,” Journal of Political Philosophy 20 (4): 432-55.

Hague Conference on Private International Law. 1993. "Convention on Protection of Children and Co-operation in Respect of Intercountry Adoption,” accessed April 23, 2014, http://www.hcch.net/index_en.php?act=conventions.text\&cid=69.

Levy, Neil and Mianna Lotz. 2005. "Reproductive Cloning and a (Kind of) Genetic Fallacy," Bioethics 19: 232-250.

McLeod, Carolyn. 2007. "For Dignity or Money: Feminists on the Commodification of Women's Reproductive Labour.” In the Oxford Handbook of Bioethics, ed. Bonnie Steinbock, 258-81. Oxford, UK: Oxford University Press.

McLeod, Carolyn, and Andrew Botterell. 2014. "“Not for the Faint of Heart': Accessing the Status Quo on Adoption and Parental Licensing.” In Baylis and McLeod, Family-Making: 151-67.

---. Unpublished manuscript. "Licensing Parents in International Contract Pregnancies."

Okin, Susan. M. 1990. “A Critique of Pregnancy Contracts: Comments on Articles by Hill, Merrick, Shevory, and Woliver," Politics and the Life Sciences 8 (2): 205-10.

Overall, Christine. 2014. "What is the Value of Procreation?" In Baylis and McLeod: FamilyMaking: 89-108.

Palacios, Jesús, and David M. Brodzinsky. 2010. "Review: Adoption Research. Trends, Topics, Outcomes," International Journal of Behavioral Development 34(3): 270-84. 
Pande, Amrita. 2009. 'Not an 'Angel', Not a 'Whore': Surrogates as 'Dirty' Workers in India," Indian Journal of Gender Studies 16 (2): 141-73.

Panitch, Vida. 2013. “Global Surrogacy: Exploitation to Empowerment,” Journal of Global Ethics 9 (3): 329-43.

Permanent Bureau, Hague Conference on Private International Law. 2012. "A Preliminary Report on the Issues Arising from International Surrogacy Arrangements,” accessed April 23, 2014, http://www.hcch.net/upload/wop/gap2012pd10en.pdf.

Re X \& Y (Foreign Surrogacy) [2009] Fam 71.

Rulli, Tina. 2014. “The Unique Value of Adoption.” In Baylis and McLeod, Family-Making: 109-28.

---. Unpublished manuscript. "Preferring a Genetically-Related Child."

Satz, Debra. 1992. "Markets in Women's Reproductive Labor,” Philosophy \& Public Affairs 21 (2): 107-131.

Save the Children. 2009. "Keeping Children Out of Harmful Institutions: Why We Should Be Investing in Family-Based Care,” accessed April 23, 2014, http://www.savethechildren.org.uk/sites/default/files/docs/Keeping_Children_Out_of_Har mful_Institutions_Final_20.11.09_1.pdf.

Secretary-General. 2006. "Report of the Independent Expert for the United Nations Study on Violence Against Children.” Delivered to the General Assembly, 29 Aug. UN Doc A/61/299, accessed April 23, 2014, http://www.unicef.org/violencestudy/reports/SG_violencestudy_en.pdf.

Shalev, Carmel. 1991. Birth Power: The Case for Surrogacy. New Haven: Yale University Press. 
Shultz, Marjorie M. 1990. "Reproductive Technology and Intent-Based Parenthood: An Opportunity for Gender Neutrality,” Wisconsin Law Review 297: 287-398.

Trimmings, Katarina, and Paul Beaumont. 2011. "International Surrogacy Arrangements: An Urgent Need for Legal Regulation at the International Level," Journal of Private International Law 7 (3): 627-47.

Van Ijzendoorn, Marinus H. and Femmie Juffer. 2006. "The Emanuel Miller Memorial Lecture 2006: Adoption as Intervention. Meta-analytic evidence for massive catch-up and plasticity in physical, socio-emotional, and cognitive development," Journal of Child Psychology and Psychiatry 47 (12): 1228-45. 